\title{
Somatostatin mRNA: Regional Variation in Hybridization Densities in Individual Neurons
}

\author{
George R. Uhl and Cathrine A. Sasek \\ Howard Hughes Medical Institute at Harvard Medical School and Massachusetts General Hospital, and \\ Department of Neurology, Massachusetts General Hospital, Boston, Massachusetts 02114
}

\begin{abstract}
Somatostatin mRNA is detected by in situ hybridization of ${ }^{35} \mathrm{~S}-$ labeled single-stranded cDNA probes to coronal sections of the rat brain that include the periventricular nucleus of the hypothalamus. Features supporting hybridization specificity include its anatomic distribution, the results of studies using multiple cDNA probes, RNAase experiments, competition studies, and correlations with patterns of somatostatin peptide immunostaining in adjacent sections. The hybridization densities vary strikingly from region to region, with highest densities in the periventricular nucleus and more modest levels in areas such as the cerebral cortex and the striatum. On the basis of the results of in situ and immunohistochemical approaches, we suggest that this variation is due to regional differences in the density of hybridization per positive cell, as well as to regional variation in the densities of somatostatinergic perikarya.
\end{abstract}

Somatostatin is a neuropeptide family whose principal member is a 14 amino acid peptide that is found in neurons lying in many nuclei distributed widely through the neuraxis (BennettClark et al., 1980; Elde and Parsons, 1975; Finley et al., 1981; Johansson et al., 1984). Somatostatin-containing neurons lying in different zones have been differentially implicated in such brain activities as neuroendocrine, motor, autonomic, sensory, and higher cortical functions (Reichlin, 1983). It is frequently assumed that somatostatin-containing neurons lying within one brain nucleus will display greater functional similarity to one another than to somatostatin-containing neurons that lie in a different brain nucleus (Bjorklund and Hökfelt, 1984a, b; Emson, 1983; Uhl, 1986a). However, means for direct demonstration of differential functions for cells using somatostatin but lying in different brain regions have not been readily available.

Recent identification of the nucleotide sequence coding for preprosomatostatin has facilitated study of somatostatin mRNA using hybridization techniques (Goodman et al., 1980, 1983; Montminy et al., 1984; Shen and Rutter, 1984). In several different neuroendocrine systems, known variations in the activities of peptidergic cells are closely paralleled by alterations in their expression of the genes for their secreted products (Barinaga et al., 1983; Burbach et al., 1984; Chin et al., 1985; Diamond and Goodman, 1985; Eberwine and Roberts, 1984; Kilpatrick et al., 1984; Murdoch et al., 1983). Assessment of the cellular content of transmitter-specific mRNAs can thus provide

Received Jan. 24, 1986; revised May 13, 1986; accepted May 14, 1986.

We gratefully acknowledge discussions with Drs. J. Habener and G. Heinrich; excellent technical assistance from $\mathrm{K}$. Hill and J. Evans, and careful assistance with the manuscript by S. Cronin. This work, from the Howard Hughes Medical Institute Neuroscience Laboratories, Boston, was also supported by the McKnight Foundation, Sloan Foundation, American Parkinson Disease Association, NIMH, and NINCDS.

Correspondence should be addressed to Dr. George R. Uhl, Wellman 405, Massachusetts General Hospital, 50 Blossom Street, Boston, MA 02114

Copyright (C) 1986 Society for Neuroscience $0270-6474 / 86 / 113258-07 \$ 02.00 / 0$ a means of measuring gene expression and may reflect the functional transmitter-synthesizing and releasing activity of peptidergic neurons under certain circumstances (Mocchetti et al., 1984; Tang et al., 1983; Uhl and Reppert, 1986; Uhl et al., 1985). In situ hybridization techniques can allow identification of neurons containing peptide-specific mRNAs and relative quantitation of hybridization densities in individual neurons located in different brain regions (Gee and Roberts, 1983; Gee et al., 1983; McAllister et al., 1984; Uhl et al., 1985; Wolfson et al., 1985).

We now report development and validation of an in situ technique to detect somatostatin mRNAs in sections of rat brain. Using this technique, we describe region-to-region variations in brain hybridization densitics. We have focused on analysis of 3 somatostatin-containing regions implicated in different brain functions: (1) the periventricular nucleus of the hypothalamus, involved in neuroendocrine function; (2) the striatum, implicated in motor regulation; and (3) the entorhinal cerebral cortex, implicated in "higher cortical" functions (Reichlin, 1983). Using film autoradiography, emulsion autoradiography, and correlations with immunohistochemical staining in adjacent sections, we have adduced evidence for 2 sources for this regional variation in hybridization densities. First, regional differences in the densities of neuronal perikarya containing somatostatin and its mRNA contribute to some of this variability. Second, we describe region-to-region differences in the density of somatostatin hybridization per positive cell. We discuss the implications of these findings for ascribing differential functional activities to somatostatin neurons located in different brain regions.

\section{Materials and Methods}

\section{Tissue}

Male Sprague-Dawley rats, $200 \mathrm{gm}$, were maintained on a $12 \mathrm{hr}: 12 \mathrm{hr}$ day-night cycle with ad lib access to food and water. Forty-eight hours before sacrifice, some animals were injected in the lateral ventricle with $50 \mu \mathrm{g}$ of colchicine in $2 \mu \mathrm{l}$ of saline solution over $5 \mathrm{~min}$. Analysis of tissue from 6 animals is reported here: 2 individuals injected with colchicine, 2 "sham-operated" controls in whom the cannulae was inserted but only vehicle administered, and 2 unoperated controls. Similar results were obtained in 10 other animals. Rats were anesthetized with chloral hydrate, and perfused with $2 \%$ depolymerized paraformaldehyde $/ 0.5 \%$ glutaraldehyde/ $75 \mathrm{~mm}$ polylysine/37.5 mm sodium phosphate, $\mathrm{pH}$ 7.4/ $10 \mathrm{~mm}$ sodium periodate to approximately $1 \mathrm{ml} / \mathrm{gm}$ of body weight (Uhl et al., 1985). Brains were removed, postfixed in the same fixative for $90 \mathrm{~min}$ at $4^{\circ} \mathrm{C}$, soaked for an additional $2 \mathrm{hr}$ in $15 \%$ sucrose in phosphate buffer, cut into slabs, and rapidly frozen on cryostat chucks using powdered dry ice or liquid nitrogen. Five (colchicine-pretreated) or 10 (non-colchicinized) micron sections of appropriate areas were cut on a Bright/Hacker cryostat and thaw-mounted onto slides. Thinner sections of colchicine-pretreated brains were cut to allow identification of some single neurons in each of 2 serial sections, allowing correlations between immunohistochemistry and in situ hybridization. Slides pretreated by acetylation and coated with Denhardt's solution $(0.02 \% \mathrm{BSA}$. 
$0.02 \%$ Ficol $/ 0.02 \%$ polyvinylpirolidine) were used for sections destined for in situ hybridization. Sections destined for immunohistochemistry were thaw-mounted onto chrome alum/gelatin-coated slides.

Sections for in situ hybridization were pretreated for $20 \mathrm{~min}$ at $22^{\circ} \mathrm{C}$ with $0.2 \mathrm{M} \mathrm{HCl}$, and $50 \mathrm{~min}$ at $37^{\circ} \mathrm{C}$ with proteinase $\mathrm{K}(1 \mu \mathrm{g} / \mathrm{ml}$ in 10 mM Tris $\mathrm{HCl}$, pH 7.4/2 mM calcium chloride) as described (Brahic and Haasc, 1978; Uhl ct al., 1985). In some expcriments, slides were incubated for $30 \mathrm{~min}$ in $25 \mu \mathrm{g} / \mathrm{ml}$ ribonuclease A to establish a control (Gee and Roberts, 1983). Slides were then dehydrated in ethanol and air-dried at room temperature.

\section{Probe preparation}

mRNA-sense template oligonucleotides corresponding to 2 regions of the rat preprosomatostatin mRNA extending from codon 26 to the first base codon of 41 (SMS 20) and from codon 46 to the first base of codon 61 (SMS 21) (Goodman et al., 1983) were synthesized chemically using an Applied Biosystems oligonucleotide synthesizer. Antisense 17 base cDNA "primers" complementary to regions beginning 6 bases from the 5 ' end of the "template" strand mRNA were synthesized. These complementary DNA sequences were allowed to hybridize to each other, and the antisense strand extended using Klenow fragment of DNA polymerase I, ${ }^{35} \mathrm{~S}$-labeled dCTP and dATP (Amersham) and unlabeled dGTP and dTTP as described (Uhl et al., 1985). Radiolabeled product was separated from the template using $12 \%$ polyacrylamide gel electrophoresis under denaturing conditions and eluted using boiling water. Product specific activity was ca. $12,000 \mathrm{Ci} / \mathrm{mmol}$. In control experiments, similar ${ }^{35} \mathrm{~S}$-labeled anti-mRNA sense oligonucleotide probes directed against vasopressin and neuropeptide $Y$ mRNAs were used.

\section{Primary antisera}

A rabbit antiserum to somatostatin 14 was kindly donated by Drs. Robert Elde and Virginia Seybold. The generation and characterization of this antiserum has been previously described (Maley and Elde, 1982; Sasek et al., 1984; Schultzberg et al., 1980). The antiserum was found to be specific with absorption controls, with Larsson's immunoblotting technique (Larsson, 1981), and in its recognition of peptides coupled to Sepharose beads.

\section{Competition experiments}

In some experiments, $2 \mathrm{pmol}$ of unlabeled DNA/ $\mu$ l complementary to or the same as the labeled probe was added to the hybridization mixtures in order to establish a control.

\section{Hybridization and washing}

${ }^{35}$ S-labeled antisomatostatin $\mathrm{cDNA}, 1 \times 10^{4} \mathrm{cpm}$, was applied to each tissue section in $0.8 \mathrm{M} \mathrm{NaCl}, 7 \mathrm{~mm}$ Tris $\mathrm{HCl}(\mathrm{pH} 7.4), 1.3 \mathrm{mg} \mathrm{BSA} / \mathrm{ml}$, $26 \mathrm{mg}$ polyvinylpyrolidine/dl, $26 \mathrm{ml}$ Ficol/dl, $0.13 \mathrm{gm}$ dextran sulfate/ $\mathrm{ml}, 0.3 \mathrm{mg}$ salmon sperm DNA $/ \mathrm{ml}, 0.6 \mathrm{~mm}$ DTT, $0.6 \mathrm{~mm}$ EDTA, and $60 \%$ (vol/vol) deionized formamide. The hybridization and washing were performed as described (Uhl et al., 1985). Autoradiograms were generated by apposition of LKB ultrofilm and apposition of emulsioncoated coverslips (Kodak NTB 2).

\section{Immunohistochemistry}

Tissues were processed according to the avidin-biotin method following overnight incubation with 1:500 dilution of rabbit anti-somatostatin antiserum. Sections were rinsed and incubated in biotinylated antirabbit antibody for $1 \mathrm{hr}$, rinsed, and incubated with the peroxidaseconjugated avidin for $1 \mathrm{hr}$. The sections were then incubated for $7 \mathrm{~min}$ in $0.1 \%$ diaminobenzidine tetrahydrochloride in $0.1 \mathrm{M}$ Tris buffer $(\mathrm{pH}$ 7.2 ) and equal volumes of $0.02 \%$ hydrogen peroxide. Sections were washed for $5 \mathrm{~min}$ in distilled water, dried, and coverslipped with Permount.

In some experiments, $1 \mu \mathrm{g} / \mathrm{ml}$ of somatostatin 14 or somatostatin 28 was added to the diluted primary antiserum prior to incubation with sections to establish a control.

\section{Analysis}

Optical densities in regions of rat brain were determined on LKB U1trofilm autoradiographic images by means of the RAAS system (Amersham/Loats Associates, Westminster, MD). This system uses a $256 \times$ 256 pixel matrix and provides measurements of averaged optical densities overlying irregular regions of interest. Anatomical boundaries were confirmed by analysis of toluidine blue-stained adjacent sections. A linear relationship between film optical density and radioactivity was confirmed using ${ }^{35} \mathrm{~S}$-brain paste standards of known activity, cut at 5 or $10 \mu \mathrm{m}$ as appropriate (Uhl et al., 1985).

Two modes of microscopic analysis were applied to the immunohistochemical and emulsion autoradiographic images generated in the study. In both cases, selection of sections through anterior portions of the periventricular hypothalamus allowed study of spatially separated neurons that were positive for somatostatin markers. In serial sections of tissue taken from colchicine-pretreated animals, correlative immunohistochemical/in situ hybridization analyses were undertaken (method A).

In method $\mathrm{A}$, somatostatin-immunoreactive neurons were localized in immunohistochemically stained sections and their relationships to adjacent landmarks (blood vessels, aspects of the third ventricle, rhinal sulcus, etc.) noted. Attempts were then made to identify the same neuron in the adjacent toluidine blue-stained section underlying the in situ hybridization emulsion autoradiogram. Only neurons whose representation in the toluidine blue-stained sections included their nuclei were included. After determination of an appropriate cell, the plane of focus was moved from the level of the tissuc to the level of the emulsion, and autoradiographic grains lying in a $10 \times 10 \mu \mathrm{m}$ zone overlying the neuron were counted manually.

A second mode of analysis was also applied to in situ autoradiograms from tissues obtained from non-colchicine-pretreated animals (method B). In this mode, the emulsion overlying regions of interest was scanned to find the highest areas of grain density. Artifacts related to scratches in the emulsion or tissue folds were excluded. After identification of 1 of these elevated densities, the plane of focus was returned to the underlying tissue. In cases where a neuronal cell body lay under the elevated grain density, the plane of focus was readjusted to the emulsion layer, and grains in a $10 \times 10 \mu \mathrm{m}$ area overlying the individual neuron were counted.

Background grain densities were obtained for each section from ten $10 \times 10 \mu \mathrm{m}$ arcas of cmulsion away from tissuc. These values (ca. 3 grains $/ 10 \mu \mathrm{m}^{2}$ ) were subtracted from observed values overlying cells before further analysis to provide a correction for autoradiographic background.

\section{Results}

\section{Specificity}

Use of both of the somatostatin probes results in hybridization that satisfies several critera for somatostatin-specificity. The regional distribution of this hybridization parallels the regional distribution of somatostatin-immunoreactive neurons noted in immunohistochemical studies. Thus, there are high hybridization densities over the periventricular nucleus of the hypothalamus and moderate to intermediate hybridization densities over cerebral cortical and striatal zones found in the same tissue sections (Fig. 1). Using each ${ }^{35} \mathrm{~S}$-labeled probe, hybridization is eliminated by competition with the appropriate complementary or same-sense sequence (Fig. 2) but not by competition with unlabeled cDNAs complementary to vasopressin or neuropeptide Y. Hybridization patterns noted with ${ }^{35} \mathrm{~S}$-labeled somatostatin cDNAs are different from those obtained with similarly prepared cDNAs directed against vasopressin or neuropeptide Y (data not shown). RNAase treatment of sections also results in loss of specific hybridization (Fig. 2). While some investigators believe that the specificity of in situ hybridization is best demonstrated by experiments in which sections are prehybridized with excess anti-mRNA-sense probe, other workers stress the need to apply a number of tests to assess hybridization specificity (Lewis et al., 1985; Uhl, 1986b).

Immunohistochemical staining also shows internal evidence for specificity. Staining patterns resemble those noted in other immunohistochemical studies. High densities of immunoreactive fibers and terminals are seen in the periventricular nucleus of the hypothalamus, while more modest densities are noted in the cerebral cortex and striatum (Finley ct al., 1983; Johansson et al., 1984). In tissues from animals pretreated by intraventric- 

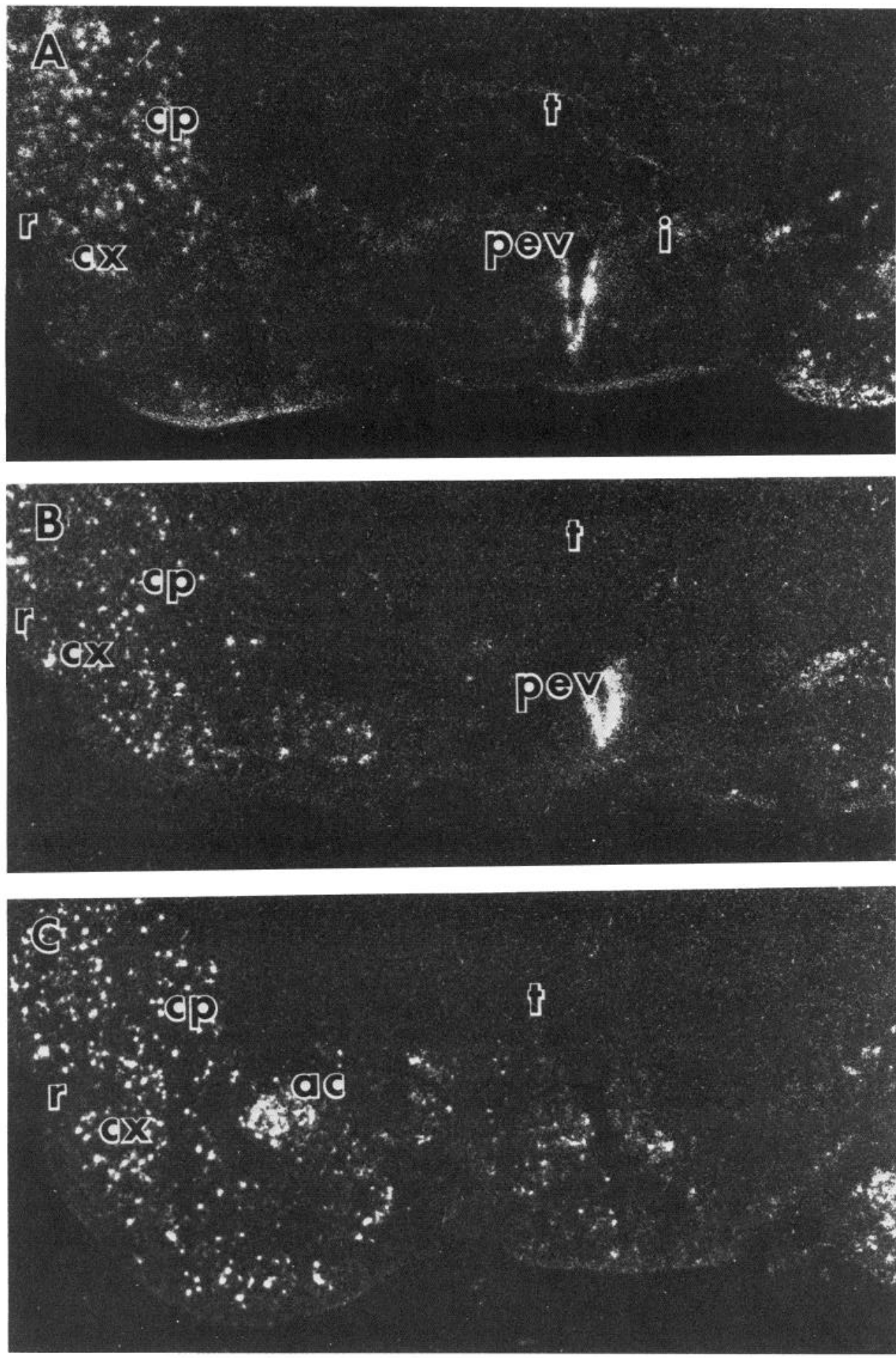

Figure 1. Prints of film autoradiograms of in situ hybridization densities in coronal sections of rat brain at levels containing the periventricular nucleus of the hypothalamus (pev) and the central nucleus of the amygdala (ac). Increased whiteness corresponds to increased grain densities in these images. Sections, $5 \mu \mathrm{m}$, were hybridized with $10^{4} \mathrm{dpm} / \mu \mathrm{l}$ each of ${ }^{35} \mathrm{~S}$-labeled-2 $1^{\prime}$ and SMS-20', as described above, and exposed to film for $12 \mathrm{~d}$. $c p$, striatum; $c x$, entorhinal cortex; $r$, rhinal sulcus; $i$, zona incerta; $t$, midthalamus. Magnification, $\times 15$ before reduction. ular injection of colchicine, dense immunopositive cell bodies are noted in the periventricular hypothalamic nucleus (Fig. 3A), while more scattered immunopositive perikarya are found in cerebral cortical and striatal zones. Interestingly, nonquantitative observations of immunohistochemical staining densities in sections from several animals reveals that the density of staining over periventricular hypothalamic cells is higher than the staining density over immunopositive cells from the striatum or cerebral cortex. Immunohistochemical staining patterns are eliminated by adsorption of the primary antiserum with somatostatin 14 or 28 (data not shown).

\section{Immunohistochemical/in situ hybridization correlations}

Additional evidence for specificity derives from correlations between immunohistochemical staining and in situ hybridization grain densities. In many cases, individual immunopositive cells can be identified in toluidine blue stains of adjacent sections processed for in situ hybridization. In these sections, hybridization densities can be seen over many of the same cells (Fig. 3). Study of these sections also shows evidence that some neurons sampled in 1 section may not be adequately represented in the adjacent section (Fig. 3). Immunopositive neuronal peri- 

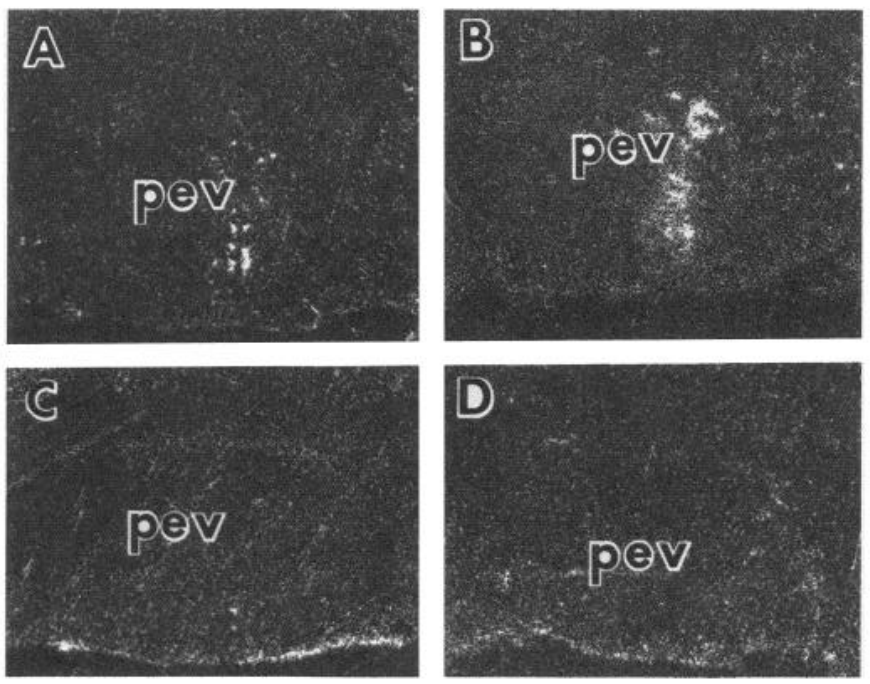

Figure 2. Prints of film autoradiograms of in situ hybridization densities in the periventricular hypothalamus (pev). A, SMS-20' hybridization, anterior pev. $B$, SMS-21' hybridization, mid-pev. $C$, Semiconsecutive section to $B$, treated identically except that $500 \mathrm{fmol} / \mu \mathrm{l}$ unlabeled oligonucleotide complementary to SMS-2 $1^{\prime}$ was added to the hybridization mixture to establish a control. $D$, Semiconsecutive section to $B$, treated identically except for predigestion with $25 \mu \mathrm{g} / \mathrm{ml}$ RNAase A, as described above. Magnification, $\times 15$ before reduction.

karya whose nuclei are well represented in the immunostained section are occasionally not well represented by either in situ hybridization densities or by a toluidine blue-stained cell profile in the adjacent in situ hybridization section. Conversely, some neurons displaying in situ hybridization densities do not appear in the adjacent immunostained section.

\section{Regional variation}

Both emulsion and film autoradiograms reveal substantial regional variation in the density of somatostatin mRNA in situ hybridization with identical patterns in normal and sham-operated control animals. Analysis of film autoradiograms reveals that hybridization densities are highest over the periventricular nucleus of the hypothalamus. High densities are noted over the area of the central nucleus of the amygdala, and densities higher than background can be identified in cerebral cortical laminae, hippocampal zones, and other hypothalamic and amygdaloid areas (Fig. 1). Regional optical density determination demonstrates that hybridization over the periventricular nucleus is 2.5 times the density of hybridization over the deeper layers of the cerebral cortex (Table 1). Densities over the gray matter of the mid-thalamus are substantially lower, while striatal values were similar to those noted in cerebral cortex.

In microscopic examination of emulsion autoradiograms, hybridization densities over individual positive neurons within a given region are similar to one another, as reflected in the modest values for standard error of the mean (Table 2). On the other hand, these estimates of per-cell hybridization density vary substantially from region to region (Fig. 4; Table 2). Hybridization densities over individual periventricular nuclear cells are 2-3 times greater than hybridization densities over individual neurons localized in the striatum or cerebral cortex (Fig. 4). Densities over individual striatal or cerebral cortical neurons, on the other hand, are similar to each other. Grain densities determined by method A over identified immunopositive cells in colchicine-pretreated animals and densities determined by method B over the maximally dense cells in a given region in non-colchicine-pretreated animals show similar patterns (Table 2).
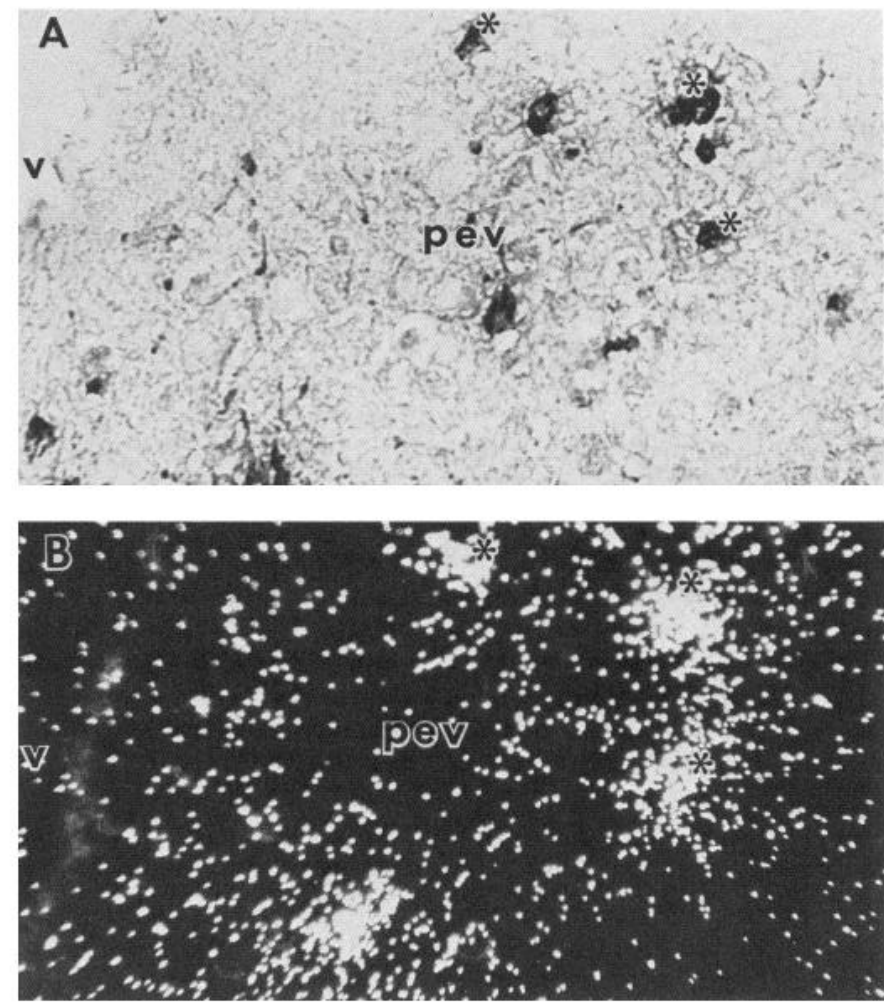

Figure 3. Somatostatin markers in matched fields of the periventricular nucleus of the hypothalamus (pev) in $5 \mu \mathrm{m}$ sections from a colchicine-treated animal. $A$, Immunostained section showing somatostatinimmunoreactive perikarya (bright-field photomicrograph). B, In situ hybridization densities in the same area as $A$, in the section adjacent to $A$. (Dark-field photomicrograph focused on grains in this emulsion autoradiogram.) Cells marked with asterisks in $A$ are present in both adjacent sections. These immunopositive neurons correspond to the hybridization densities marked in $B$, and are included in the analysis of data presented in Table $2 . v$, third ventricle. $40 \times$ objective magnification.

\section{Discussion}

Our results should be discussed in light of the strengths and limitations of the methods, potential explanations for the observed results, and possible implications of this approach for determination of regional transmitter-specific brain function.

Several features of the observed immunohistochemical staining and in situ hybridization suggest that somatostatin peptide and preprosomatostatin mRNA are being identified in these histologic techniques. The distribution of the in situ hybridization densities parallels the density of somatostatin-immunoreactive cells and argues for specificity. Further, in adjacent sections taken from the same colchicine-pretreated animals, we have identified individual neurons that are immunoreactive with somatostatin antibodies and hybridize with ${ }^{35} \mathrm{~S}$-labeled antisomatostatin cDNA probes. Two different probes directed against different regions of the preprosomatostatin mRNA recognized it in identical patterns, while similar-sized cDNA probes directed against other neuropeptide mRNAs display different patterns. Competition experiments demonstrate further specificity; competition with excess cDNA corresponding to the probes utilized virtually eliminates hybridization. This approach has been advocated as providing strong evidence for hybridization specificity (Lewis et al., 1985). We have also found that RNAase pretreatment of sections substantially reduces hybridization densities. Preabsorption controls, the neuronal nature of the immunostaining patterns, and the regional distribution of stain- 
Table 1. Somatostatin mRNA hybridization densities over brain regions

\begin{tabular}{ll} 
Region & Mean optical density \\
\hline Periventricular hypothalamus & $0.1688 \pm 0.012$ \\
Central amygdala & $0.1662 \pm 0.018$ \\
Cerebral cortex (entorhinal) & $0.0691 \pm 0.008$ \\
Striatum & $0.0636 \pm 0.018$ \\
Thalamus (mid) & $0.0322 \pm 0.005$
\end{tabular}

Film autoradiograms of a coronal section taken from the level of the periventricular nucleus of the hypothalamus from 3 animals were subjected to regional optical density determination using the Loats/Amersham RAAS system. Values presented here represent mean \pm SEM optical densities for each region of interest.

ing each also argue in favor of specificity in immunohistochemical studies.

The method that we have chosen to examine hybridization densities corresponding to individual neurons was based on several issues of technique. Several workers have reported combined immunohistochemical/in situ hybridization studies (Bloch et al., 1984, 1985; Brahic et al., 1984; Gendelman et al., 1985; Shivers et al., 1986). When attempting to perform these techniques serially in the same tissue sections in preliminary studies, however, we, and at least some other workers, have noted substantial and variable loss of hybridization signal after exposure of the tissue to immunohistochemical procedures (e.g., Gendelman et al., 1985). We therefore explored methods for immunostaining and hybridizing to adjacent sections, cut at $5 \mu \mathrm{m}$ so that many of the same neuronal cell bodies could be identified in both adjacent sections. Preliminary studies with the technique yielded good, consistent patterns of in situ hybridization, with acceptable immunostaining. In these studies, reduction in the glutaraldehyde content of our fixative yielded lower immunohistochemical backgrounds, but the change also reduced the density of in situ hybridization (C. Sasek and G. Uhl, unpublished observations).

In quantitating studies in adjacent sections, it is conceivable that results could be biased by acquisition of only a partial thickness of a neuronal cell body in the section processed for in situ hybridization. We have attempted to reduce the influence of this potential bias by counting grains only over cells whose nucleus is clearly seen in the stained tissue section of the in situ hybridization autoradiograms. Although nuclei can lie to one side of a neuron, this maneuver should decrease the likelihood of underestimating a cell's density due to partial volume effects.

Colchicine pretreatment of animals has been reported to have a variable effect on mRNA densities (Young et al., 1985). Accordingly, we have pursued our analysis in 2 fashions. First, in
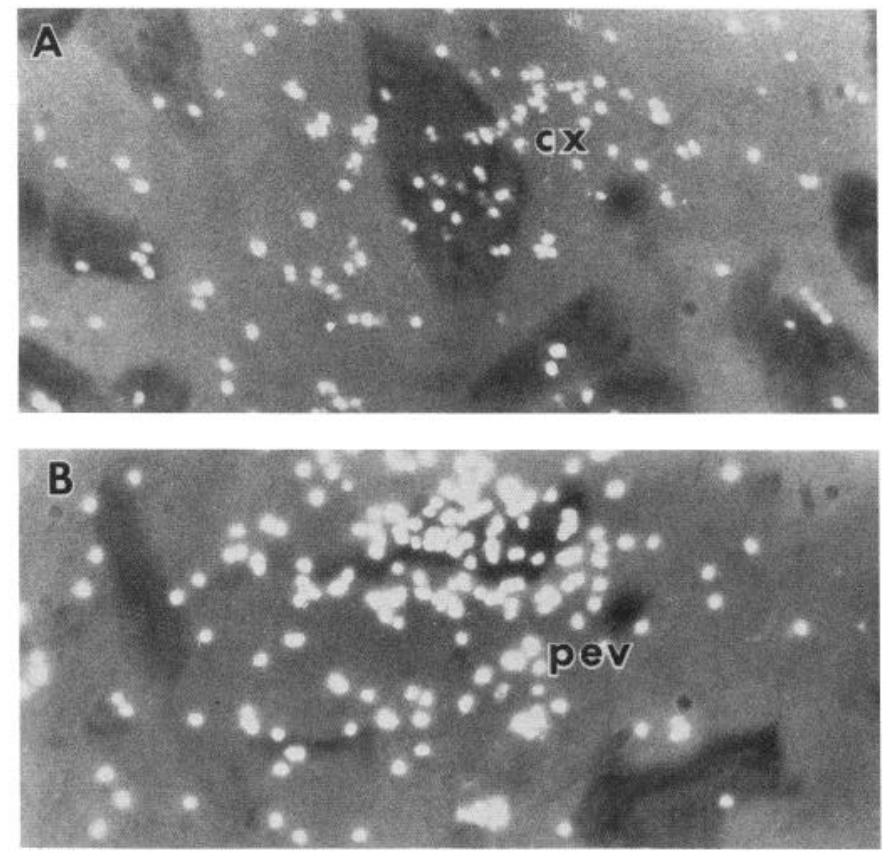

Figure 4. In situ hybridization densities above individual neurons $(A)$ in entorhinal cortex $(c x)$ and infrangular layers and $(B)$ in periventricular hypothalamus (pev). Double-exposure photomicrographs of emulsion autoradiograms, with the bright-field exposure focused on the positive neuronal cell body and the dark-field exposure focused on the autoradiographic grains overlying the same field. Labeling over the positive cerebral cortical neuron is several times greater than the background densities noted over the neuron in the upper left portion of $A$. Since the grain densities over periventricular neurons $(B)$ were close to emulsion saturation, the exposure could not be increased to amplify the signal in A. $100 \times$ objective magnification.

colchicine-pretreated animals where we are able to immunostain peptide-containing perikarya with confidence, we have examined hybridization densities over cells that could be identified as immunopositive (method A). Second, in material from animals not pretreated with colchicine, we are also able to identify the cells in a given brain region with the maximum hybridization densities (method B). Since the same relationship between hybridization densities over hypothalamic and extrahypothalamic nuclei is evident using both methods of analysis, this difference between cell groups does not appear to be attributable to influences of colchicine pretreatment or to a particular biased mode of determining the immunopositive and hybridization-positive cells.

Table 2. Somatostatin mRNA hybridization densities over individual neurons in different brain regions

\begin{tabular}{|c|c|c|c|}
\hline & \multicolumn{3}{|c|}{ Density (grains $/ 10 \mu \mathrm{m}^{2}$ ) } \\
\hline & $\begin{array}{l}\text { Periventricular } \\
\text { hypothalamus }\end{array}$ & Striatum & $\begin{array}{l}\text { Cerebral } \\
\text { cortex } \\
\text { (entorhinal) }\end{array}$ \\
\hline $\begin{array}{l}\text { I. Over immunopositive neurons } \\
\text { (colchicine-pretreated animals: method A) }\end{array}$ & $\begin{array}{l}21.1 \pm 1.77 \\
(n=24)\end{array}$ & $\begin{array}{l}5.6 \pm 0.86 \\
(n=10)\end{array}$ & $\begin{array}{l}7.3 \pm 0.97 \\
(n=18)\end{array}$ \\
\hline $\begin{array}{l}\text { II. Maximal density over neurons } \\
\text { (nonpretreated animals: method B) }\end{array}$ & $\begin{array}{l}18.0 \pm 0.77 \\
(n=40)\end{array}$ & $\begin{array}{l}6.8 \pm 0.38 \\
(n=46)\end{array}$ & $\begin{array}{l}5.4 \pm 0.26 \\
(n=54)\end{array}$ \\
\hline
\end{tabular}

Emulsion autoradiograms of 12 coronal sections taken from the level of the periventricular nucleus of the hypothalamus from 5 animals and adjacent immunostained sections from the colchicine-treated individuals were subjected to 2 modes of cell hybridization density determination as described in the text. Values presented here represent the mean \pm SEM for grain densities overlying a $10 \times 10 \mu \mathrm{m}$ area of the neuronal perikarya in each region of interest. 
Could possible region-to-region differences in mRNA losses during, for example, fixation or pretreatment account for the results presented here? Preliminary observations using ${ }^{3} \mathrm{H}$-oligouridine $\mathrm{CRNA}$ probes to hybridize to polyadenylated tracts of total cellular poly $\left(\mathrm{A}^{+}\right)$mRNAs (Angerer and Angerer, 1981) do not support such a postulated mechanism, as cerebral cortical cellular hybridization densities appear to be at least as great as those in the periventricular hypothalamus (G. Uhl, unpublished observations).

Our observed results suggest that region-to-region variability in somatostatin mRNA hybridization densities may therefore be due both to regional differences in the densities of immunopositive cells and to differences in the density of hybridization per cell. Conceivably, each of these factors could influence the abilities of particular neurotransmitter systems to modulate particular regional brain functions.

As we and others have noted, peptidergic neurons generally lack reuptake mechanisms and, over a period of time, must match their peptide-producing and peptide-releasing activities (Iverson, 1983; Uhl, 1986a). This match between the peptide synthetic rate and functional activity of a neuronal population could be achieved by regulation of transcriptional rates, mRNA stability, posttranscriptional processing, translational activity, and/or posttranslational peptide processing (Habener, 1981). In many neuronal and neuroendocrine systems, regulation of transcriptional rate and mRNA stability are combined so that cellular levels of peptide-specific mRNA provide good markers for the functional activities of particular peptidergic cells (Barinaga et al., 1983, 1985; Diamond and Goodman, 1985; Eberwine and Roberts, 1984; Kilpatrick et al., 1984; Murdoch et al., 1983). If this is true in the brain, our findings could point toward substantially greater functional activity in periventricular hypothalamic than in cerebral cortical or striatal somatostatincontaining cells. These observations could thus reflect higher rates of both peptide synthesis and peptide release in the hypothalamus.

These in situ hybridization results could fit with our immunohistochemical observations suggesting denser immunostaining in periventricular hypothalamic neurons than in other neuronal groups in the same tissue sections. Further, they may accord with known aspects of the physiology of these peptidecontaining neuronal groups. Somatostatin can function as a hormone, modulating anterior pituitary release of growth hormone and other hormones (Reichlin, 1983). In addition, it can function as a neurotransmitter, interacting with receptors and influencing firing rates of cells in many parts of the neuraxis. Periventricular neurons contribute much of the somatostatin that acts through portal capillaries to influence the pituitary (Reichlin, 1983). Our findings could conceivably suggest that this hormonal mode of peptide utilization requires greater synthetic activity than the neurotransmitter-like uses observed in other somatostatin-containing neuronal groups. We have recently made similar observations while studying vasopressin mRNA hybridization in situ (Uhl and Reppert, 1986; Uhl et al., 1985). Comparison of high hybridization densities over the supraoptic nucleus, whose vasopressin is substantially committed to neuroendocrine uses, and lower densities over the suprachiasmatic nucleus, whose peptide products are not secreted into blood, suggests that a similar relationship may also obtain in this system. Extension of this approach to other brain regions and other neuropeptide-utilizing systems may allow us to further test the general utility of this technique for assessment of region-toregion differences in gene expression of peptide-utilizing neurons and neuroendocrine cells.

\section{References}

Angerer, L. M., and R. C. Angerer (1981) Detection of poly A+ RNA in sea urchin eggs and embryos by quantitative in-situ hybridization. Nucleic Acids Res. 9: 2819-2840.
Barinaga, M., G. Yamonoto, C. Rivier, W. Vale, R. Evans, and M. G. Rosenfeld (1983) Transcriptional regulation of growth hormone gene expression by growth hormone-releasing factor. Nature 306: 84-85.

Barinaga, M., L. M. Bilezikjian, W. W. Vale, M. G. Rosenfeld, and R. E. Evans (1985) Independent effects of growth hormone releasing factor on growth hormone release and gene transcription. Nature 314 : 279-281.

Benpett-Clarke, C., M. A. Romagnano, and S. A. Joseph (1980) Distribution of somatostatin in the rat brain: Telencephalon and diencephalon. Brain Res. 188: 473-486.

Bjorklund, A., and T. Hökfelt (1984a) Handbook of Chemical Neuroanotomy Classical Transmitters in the CNS, Part I, Elsevier, Amsterdam.

Bjorklund, A., and T. Hökfelt (1984b) Handbook of Chemical Neuroanatomy Classical Transmitter Receptors in the CNS. Part II, Elsevier, Amsterdam.

Bloch, B., R. J. Milner, A. Baird, U. Gubler, C. Reymond, P. Bohlen, D. leGuellec, and F. Bloom (1984) Detection of the messenger RNA coding for preproenkephalin $\mathrm{A}$ in bovine adrenal by in-situ hybridization. Regulat. Peptides 8: 345-354.

Bloch, B., T. Popovici, M. J. Levin, D. Tull, and A. Kahn (1985) Transferrin gene expression visualized in oligodendrocytes of the rat brain by using in-situ hybridization and immunohistochemistry. Proc. Natl. Acad. Sci. USA 82: 6706-6710.

Brahic, M., and A. T. Haase (1978) Detection of viral sequences of low reiteration frequency by in-situ hybridization. Proc. Natl. Acad. Sci. USA 75: 6125-6129.

Brahic, M., A. T. Haase, and E. Cash (1984) Simultaneous in-situ detection of viral RNA and antigens. Proc. Natl. Acad. Sci. USA 81: 5445-5448.

Bruhn, T. O., R. E. Suttin, C. L. Rivier, and W. W. Vale (1984) Corticotropin-releasing factor regulated proopiomelanocortin messenger ribonucleic acid levels in vivo. Neuroendocrinology 39: 170-175.

Burbach, J. P. H., M. J. DeHoop, H. Schmale, D. Richter, E. R. DeKloet, J. A. TenHaaf, and D. DeWicd (1984) Differential responses to osmotic stress of vasopressin-neurophysin mRNA. Neuroendocrinology 39: 582-584.

Chin, W. W., M. A. Shupnik, D. S. Ross, J. F. Habener, and E. C. Ridgway (1985) Regulation of the alpha and thyrotropin beta-subunit messenger ribonucleic acids by thyroid hormones. Endocrinology 116: 873-878.

Diamond, D. J., and H. M. Goodman (1985) Regulation of growth hormone messenger RNA synthesis by dexamethasone and triiodothyronine. J. Mol. Biol. 181: 41-62.

Eberwine, J. H., and J. L. Roberts (1984) Glucocorticoid regulation of pro-opiomelanocortin gene transcription in the rat pituitary. $\mathrm{J}$. Biol. Chem. 259: 2166-2170.

Elde, R. P., and J. A. Parsons (1975) Immunohistochemical localization of somatostatin in ccll bodics of the rat hypothalamus. Am. J. Anat. 144: 541-548.

Emson, P. C. (1983) Chemical Neuroanatomy, Raven, New York.

Finley, J. C. W., J. L. Maderdrut, L. J. Roger, and P. Petrusz (1981) The immunohistochemical localization of somatostatin-containing neurons in the rat central nervous system. Neuroscience 6: 21732192.

Gee, C. E., and J. L. Roberts (1983) In-situ hybridization histochemistry: A technique for the study of gene expression in single cells. DNA 2: 157-163.

Gee, C. E., C. C. Chen, and J. L. Roberts (1983) Identification of proopiomelanocortin neurons in rat hypothalamus by in situ cDNAmRNA hybridization. Nature 306: 374-376.

Gendelman, H. E., O. Narayan, S. Molineaux, J. E. Clements, and Z. Ghotbi (1985) Slow, persistent replication of lentiviruses: Role of tissue macrophages and macrophage precursors in bone marrow. Proc. Natl. Acad. Sci. USA 82: 7086-7090.

Goodman, R. H., J. W. Jacobs, W. W. Chin, P. K. Lund, P. C. Dee, and J. F. Habener (1980) Nucleotide sequence of a cloned structural gene coding for a precursor of pancreatic somatostatin. Proc. Natl. Acad. Sci. USA 77: 5869-5873.

Goodman, R. H., D. C. Aron, and B. A. Roos (1983) Rat preprosomatostatin. J. Biol. Chem. 258: 5570-5573.

Habener, J. (1981) Principles of peptide hormone biosynthesis. In Neurosecretion and Brain Peptides, J. Martin, S. Reichlin, and K. Blick, eds., pp. 21-34, Raven, New York.

Iverson, L. (1983) Neuropeptides-what next? Trends Neurosci. 5: 293-295. 
Johansson, O., T. Hökfelt, and R. P. Elde (1984) Immunohistochemical distribution of somatostatin-like immunoreactivity in the central nervous system of the adult rat. Neuroscience 13: 265-339.

Kilpatrick, D. L., R. D. Howells, G. Fleminger, and S. Undefriend (1984) Denervation of rat adrenal glands markedly increases preproenkephalin mRNA. Proc. Natl. Acad. Sci. USA 81: 7221-7223.

Larsson, L. (1981) A novel immunocytochemical model system for specificity and sensitivity screening of antisera against multiple antigens. J. Histochem. Cytochem. 29: 408-410.

Lewis, M. E., S. Burke, T. Sherman, and S. J. Watson (1985) Evaluating specificity in in-situ hybridization histochemistry. Soc. Neurosci. Abstr. 11: 141 .

Maley, B., and R. Elde (1982) Immunohistochemical localization of putative neurotransmitters within the feline nucleus tractus solitarii. Neuroscience 7: 2469-2490.

McAllister, L. B., R. H. Scheller, E. R. Kandel, and R. Axel (1984) In-situ hybridization to study the origin and fate of identified neurons. Science 222: 800-808.

Mocchetti, I., O. Giorgi, J. P. Schwartz, and E. Costa (1984) A reduction of the tone of 5-hydroxytryptamine neurons decreases utilization rates of striatal and hypothalamic enkephalins. Eur. J. Pharmacol. 106: 427-430.

Montminy, M. R., R. H. Goodman, S. J. Horovitch, and J. F. Habener (1984) Primary structure of gene encoding rat preprosomatostatin. Proc. Natl. Acad. Sci. USA 81: 3337-3340.

Murdoch, G. H., R. Franco, R. M. Evans, and M. G. Rosenfeld (1983) Polypeptide hormone regulation of gene expression. J. Biol. Chem. 258: 15329-15335.

Reichlin, S. (1983) Somatostatin. In Brain Peptides, D. Krieger, M. Brownstein, and J. Martin, eds., pp. 711-752, Wiley, New York.

Sasek, C., V. Seybold, and R. Elde (1984) The immunohistochemical localization of nine peptides in the sacral parasympathetic nucleus and dorsal grey commisure in rat spinal cord. Neuroscience 12:855887.

Schultzberg, M., T. Hökfelt, G. Nilsson, L. Terenius, J. F. Rehfels, M. Brown, R. Elde, M. Goldstein, and S. Said (1980) Distribution of peptide- and catecholamine-containing neurons in the gastro-intestinal tract of the rat and guinea pig: Immunohistochemical studies with antisera to substance $P$, vasoactive intestinal polypeptide, enkephalins, somatostatin, gastrin/cholecystokinin, neurotensin and dopamine hydroxylase. Neuroscience 5: 689-744.

Shen, L., and W. Rutter (1984) Sequence of the human somatostatin I gene. Science 224: 168-171.

Shivers, B. D., R. E. Harlan, D. W. Pfaff, and B. S. Schachter (1986) Combination of immunocytochemistry and in-situ hybridization in the same tissue section of rat pituitary. J. Histochem. Cytochem. (in press).

Tang, F., E. Costa, and J. P. Schwartz (1983) Increase of proenkephalin mRNA and enkephalin in content of rat striatum after daily injection of haloperidol for 2 to 3 weeks. Proc. Natl. Acad. Sci. USA 80: 38413844.

Uh1, G. R. (1986a) Neurotransmitters and receptors. In Diseases of the Nervous Systems, A. Ashbury, G. McKhann, and W. MacDonald, eds., Heineman, New York.

Uhl, G. R. (1986b) Specificity. In In-situ Hybridization in Brain, G. Uhl, ed. Plenum, New York (in press).

Uhl, G. R., and S. M. Reppert (1986) Suprachiasmatic nucleus vasopressin mRNA: Circadian variation in normal and Brattleboro rats. Science 232: 390-393.

Uhl, G. R., H. H. Zingg, and J. F. Habener (1985) Vasopressin mRNA in-situ hybridization: Localization and regulation in rat hypothalamus. Proc. Natl. Acad. Sci. USA 82: 5555-5559.

Wolfson, B., R. W. Manning, L. G. Davis, R. Arentzen, and F. Baldino (1985) Co-localization of corticotropin releasing factor and vasopressin mRNA in neurons after adrenalectomy. Nature 315: 59-61.

Young, W. S., E. Mezey, and R. Seigel (1985) Quantitation of vasopressin and oxytocin mRNA: An in situ hybridization histochemical study of normal, adrenalectomized, and Brattleboro rats. Neurosci. Abstr. 1: 142. 